\title{
Парадокс гедонизма как средство обоснования морали
}

\author{
Прокофьев А.В. \\ Институт философии РАН \\ Россия, 109240 Москва, ул. Гончарная, д. 12, стр. 1; \\ Тульский государственный педагогический университет им. Л.Н. Толстого, \\ Россия, 300026, Тула, пр-т Ленина, 125 \\ E-mail: avprok2006@mail.ru
}

\begin{abstract}
Аннотация. Обоснование морали представляет собой поиск аргументов, которые могли бы продемонстрировать необходимость соблюдения моральных требований тому человеку, который сомневается в ней. Так как под моральным скептиком понимается убежденный гедонист, то обоснование морали тесно связано с доказательством противоречивости гедонизма. Один из способов такого доказательства апеллирует к «парадоксу гедонизма»: стремление получить наибольшее удовольствие не ведет к максимальной интенсивности приятных переживаний, в то время как достижение других целей может ее обеспечить. Автор реконструирует предысторию парадокса гедонизма в античной этике (в концепции «чистых удовольствий» Платона, в аристотелевском представлении о «попутном» характере удовольствия и в эпикурейском учении о дружбе), а также его прямое обсуждение новоевропейскими мыслителями: Джозефом Батлером, Джоном Стюартом Миллем, Генри Сиджвиком. В завершении представлен анализ использования парадокса в качестве первого шага обоснования морали, на котором у морального скептика должно возникнуть убеждение в существовании объективно значимых жизненных целей (среди примеров - моральная философия Пола Блумфилда и Питера Сингера).
\end{abstract}

Ключевые слова: мораль, этика, обоснование морали, парадокс гедонизма, Платон, Аристотель, Эпикур, Дж. Батлер, Дж.С. Милль, Г. Сиджвик, П. Блумфилд, П. Сингер

Благодарности: Исследование выполнено при финансовой поддержке РФФИ в рамках научного проекта № 20-011-00145 А «Обоснование морали как проблема современной этики (реконструкция, сравнение и оценка теоретических подходов)».

Для цитирования: Прокофьев А.В. 2020. Парадокс гедонизма как средство обоснования морали. NOMOTHETIKA: Философия. Социология. Право. 45 (4): 685-695. DOI 10.18413/2712-746X-202045-4-685-695

\section{The Paradox of Hedonism as a Means of Justification of Morality}

\author{
Andrey V. Prokofyev \\ RAS Institute of Philosophy \\ 12/1 Goncharnaya St, Moscow 109240, Russia \\ Tula State Lev Tolstoy Pedagogical University; \\ 125 Lenina Av. Tula 300026, Russian Federation. \\ E-mail: avprok2006@mail.ru
}

\begin{abstract}
Justification of morality requires to find some arguments that can show a moral sceptic that to carry out moral demands is necessary. Since a moral sceptic is usually understood as a hedonist, justification of morality includes the demonstration of the contradictory nature of hedonism. One of the often used methods of this demonstration is the appeal to the so-called 'paradox of hedonism'. It states that the desire to get maximum pleasure cannot possibly give us it while the desire to attain some other goals can be much more productive in hedonistic terms. The author outlines the history of the paradox in antiquity (Plato's conception of 'pure pleasures', Aristotle's understanding of pleasure as a 'supervenient'
\end{abstract}


phenomenon, the epicurean teaching on friendship) and analyzes its direct declarations in the Modern ethics (Joseph Butler, John Stuart Mill, Henry Sidgwick). Then he draws a picture of how the paradox of hedonism was turned into the first step of justification of morality. The predicament of a hedonist generated by the paradox should show him that there are some objective life-goals independent of his pleasure and pain (the position of Paul Bloomfield and Peter Singer).

Keywords: morality, ethics, justification of morality, paradox of hedonism, Plato, Aristotle, Epicurus, J. Butler, J.S. Mill, H. Sidgwick, P. Bloomfield, P. Singer

Acknowledgements: The reported study was funded by RFBR, project number 20-011-00145 (Justification of Morality as a Problem of Contemporary Ethics (the Reconstruction, Comparison and Evaluation of Theoretical Approaches)).

For citation: Prokofyev A.V. 2020. The Paradox of Hedonism as a Means of Justification of Morality. NOMOTHETIKA: Philosophy. Sociology. Law series. 45 (4): 685-695 (in Russian). DOI 10.18413/2712-746X-2020-45-4-685-695

\section{Проблема обоснования морали}

Под обоснованием морали принято понимать поиск рациональных аргументов, способных убедить людей в необходимости а) признать правильность (обязательность) нравственных требований, содержание которых сконцентрировано в предельно общем императиве «Действуй ради блага другого!», и б) соблюдать эти требования, несмотря на противодействующие этому мотивы. Занимающийся обоснованием морали философ призван обнаружить доводы, демонстрирующие иррациональность позиции морального скептика (релятивиста, аморалиста, имморалиста). Методология обоснования предполагает выявление общезначимых потребностей и свойств человека с последующей демонстрацией того, что признание и исполнение нравственных требований являются условием удовлетворения этих потребностей или сохранения этих свойств. Предъявление моральному скептику подобной связи рассматривается при этом как средство, способное снять его сомнение, трансформировать его позицию, если, конечно, он чувствителен к рациональной аргументации. Одной из самых распространенных отправных точек обоснования морали является стремление каждого человека к собственному благу. Это безусловно всеобщее стремление, отвечающее на общезначимую человеческую потребность (см. подробнее: [Прокофьев, 2017]). Самым простым выражением стремления к собственному благу и при этом не зависящим от сложных мировоззренческих и идеологических установок является стремление к получению наиболее сильных и устойчивых удовольствий. В силу этого, аргументы, обосновывающие мораль, часто формулируются как аргументы, адресованные убежденному гедонисту.

В данной статье я планирую проанализировать тот аргумент, который опирается на так называемый парадокс гедонизма. В самом общем виде парадокс гласит: стремление получить наибольшее удовольствие не ведет к максимальной интенсивности приятных переживаний, в то время как достижение других целей вполне может ее обеспечить. Во втором и третьем разделах статьи я обращусь к истории парадокса в античной и новоевропейской философских традициях, а в заключительном, четвертом - к способам его использования в современных концепциях обоснования морали.

\section{Парадокс гедонизма: античные сюжеты}

Общая логическая схема парадокса гедонизма появляется в платоновском диалоге «Филеб». В нем Платон разграничивает удовольствия. Есть удовольствия, состоящие по преимуществу в избавлении от страданий (они «смешаны со страданиями и прекращением сильнейших болей при тяжелых состояниях тела и души») [Платон, 1994, с. 58]. Ключевой пример - удовольствие от еды, связанное с удовлетворением голода. Их противопо- 
ложность - «чистые» и «истинные» удовольствия, к которым Платон относит «удовольствия, вызываемые красивыми... красками, очертаниями, многими запахами, звуками и всем тем, в чем недостаток незаметен и не связан со страданием, а восполнение заметно и приятно» [Платон, 1994, с. 63]. К удовольствию от созерцания математических фигур, прослушиванию музыки и обонянию приятных запахов он добавляет «удовольствия, получаемые от занятий науками, поскольку... в них отсутствует жажда познания и поскольку жажда эта изначально не связана с неприятностями» [Платон, 1994, с. 59].

Вторые удовольствия, по Платону, предпочтительны. У платоновского Сократа вызывает смех абсурдная позиция тех, кто, «утоляя голод, жажду и вообще все, что утоляется становлением, радуются благодаря становлению, так как оно - удовольствие, и говорят, что они не пожелали бы жить, не томясь жаждой, голодом и так далее...» [Платон, 1994, с. 63]. Этих людей притягивает сила смешанных, нечистых удовольствий, но в действительности такие удовольствия лишь кажутся более сильными или же, будучи действительного более сильными, лишь кажутся более приятными. Платон вводит сравнение двух видов удовольствий с двумя вещами: большой и окрашенной в смешанный с другими цветами белый цвет и небольшой, но выкрашенной с помощью белой краски без примесей какой-либо иной, и задает вопрос: «Какая из этих вещей белее?» Ответ очевиден: вторая. Точно также дело обстоит и с удовольствиями. Чистое всегда превосходит нечистое: «Всякое, даже незначительное и редко выпадающее нам удовольствие, раз оно чисто от страдания, приятнее, истиннее и прекраснее, чем сильное и многочисленное» (в контексте нашего рассуждения важно, что «приятнее») [Платон, 1994, с. 61]. Именно чистые удовольствия, наряду с другими составляющими (мерой, прекрасным, умом, знаниями, искусствами, правильными мнениями), оказываются неотъемлемой частью человеческого блага.

Однако их получение порождает существенную практическую проблему. Оно не может выступать в качестве мотива. Ведь характерной чертой этих, необходимых для благой жизни удовольствий, является то, что «их недостаток незаметен», а жажда их получения «отсутствует» [Платон, 1994, с. 58]. Если они будут выступать предметом желания (жажды), то они перестанут быть чистыми и несмешанными, превратятся в подобие удовлетворения голода или жажды. Отсюда следует, что их получение может быть мотивировано только стремлением к чему-то иному. Чтобы иметь чистые удовольствия надо быть вовлеченным в некоторые виды деятельности (прежде всего, в познавательную) ради них самих, а не ради их приятного эффекта. Как резюмирует Иоахим Ауфдерхайде, «чтобы обрести самые лучшие удовольствия... мы должны сфокусироваться не на удовольствии, а на деятельности или ее цели» [Aufderheide, 2011, p. 94]. С ним в целом солидаризируется Верити Харт: «Истинные удовольствия - бездействующие удовольствия, приятное ощущение, которое они вызывают, не является предметом стремления того, кому они принадлежат. Но они не являются по этой причине немотивированными. Возьмем пример истинного удовольствия от познания... в связи со знанием Сократ говорит о желании истины, но не о желании удовольствия, возникающего от стремления к истине» [Harte, 2018, p. 124]. Не удивительно, что оба исследователя античной философии находят структурное и содержательное сходство платоновской мысли с новоевропейским парадоксом гедонизма [Aufderheide, 2011; Harte, 2018].

При определенном понимании рассуждений Аристотеля об удовольствии, содержащихся в X книге «Никомаховой этики», они так же воспроизводят структуру парадокса гедонизма. Здесь Аристотель развертывает тезис, что «без деятельности не бывает удовольствия, а удовольствие делает всякую деятельность совершенной» [Аристотель, 1983, c. 275]. В качестве примеров деятельности он обсуждает чувственное восприятие, а также «мышление и умозрение». Аристотель утверждает, что «пока умопостигаемый или чувственно воспринимаемый [предмет] и то, что судит о нем или созерцает его, остаются такими, какими они должны быть, в деятельности будет удовольствие» [Аристотель, 1983, с. 275]. Это удовольствие «слито» с деятельностью, но не тождественно ей («удовольствие - это все-таки не мысль и не чувство (это [было бы] нелепо)») [Аристотель, 1983, с. 277]. 
При этом интенсивность удовольствия от деятельности вариативна. Хотя любое чувственное восприятие или любой процесс мышления сопровождаются удовольствием, «наивысшее удовольствие» будет доставлять лишь та деятельность, которую осуществляет «хорошо устроенное» чувство, направленное на «восприятие наиболее прекрасного из подлежащего восприятию данным чувством» [Аристотель, 1983, с. 274]. Именно присутствие удовольствия придает деятельности завершенный и совершенный характер. В особенности это касается «наивысшего удовольствия», порожденного сочетанием чувства, которое «хорошо устроено», и «доброкачественного» предмета. Однако эту свою роль удовольствие играет не в качестве движущей или формальной причины, то есть не так, как это делает специфика воспринимаемого предмета и способностей к его восприятию, а просто посредством дополнения. Удовольствие «делает деятельность совершенной [и полной] не как свойство, в ней заложенное, но как некая полнота, возникающая попутно, подобно красоте у [людей] в расцвете лет» [Аристотель, 1983, с. 275].

Такое соотношение качества деятельности с интенсивностью и совершенством удовольствия ставит под вопрос возможность того, чтобы увеличение удовольствия было некой самостоятельной целью. Хотя удовольствие является благом и это такое благо, без которого деятельность не может быть совершенной, его получение всецело зависит от степени совершенства деятельности. И значит именно совершенство с необходимостью превращается в единственную непосредственную цель деятеля. Ауфдерхайде резюмирует: «Аристотель придает приоритет такой установке деятеля, как любовь к определенному виду деятельности: человек делает то, что он любит делать. Если он занимается любимыми видами деятельности, то он будет также и получать от них удовольствие. Удовольствие усилит деятельность, и он сможет заниматься ей наилучшим образом. В этой связи он получит от деятельности наибольшее количество удовольствия. [А это значит, что] ... деятель получает максимум удовольствия только будучи полностью поглощенным деятельностью, не думая об удовольствии и страдании, и, в особенности, не стремясь к удовольствию» [Aufderheide, 2011, p. 194-195]. В этой характеристике также угадывается логическая структура парадокса гедонизма.

Еще одним примером присутствия парадокса гедонизма в античной философии можно считать эпикуровское понимание дружбы. В трактате «О пределах блага и зла» Цицерон характеризует разные эпикурейские позиции в отношении этого явления. Эпикурейцы первого типа «утверждают, что наслаждения друзей сами по себе не являются “желанными” в той же мере, как наши собственные» [Цицерон, 2000, с. 69]. При этом «дружбу нельзя отделить от [нашего собственного] наслаждения», поскольку она является непременным условием его получения: лишь появление друзей делает «надежду обрести наслаждение» твердой [там же]. Другими словами, дружба «не только самая верная покровительница, но и творец наслаждения» [там же]. Однако сохранить дружбу невозможно: «если [мы] не станем любить друзей наших как самих себя» [там же]. В итоге, «радости друзей доставляют нам такую же радость, как и наши собственные, и так же мы страдаем от их огорчений, как от своих собственных» [там же, с. 70]. В практическом плане эпикурейский мудрец «готов предпринять ради наслаждения друга такие же усилия, как и ради собственного» [там же].

Среди исследователей существуют разные интерпретации эпикурейского рассуждения о дружбе, которое, по словам Тима О'Киффа, предполагает возможность «любить других как самого себя на эгоистической основе». Сам О'Кифф считает, что здесь имеет место простая целесредственная связь: мудрец «относится к друзьям так, как он относится к себе, чтобы дружба была устойчивой». Слово «любовь» в формулировке «любить друзей наших как самих себя», по мнению О'Киффа, означает всего лишь практическую установку не вести себя так, чтобы собственный интерес получал предпочтение по сравнению с интересом друга. Эпикурейская любовь к друзьям - это не мотивирующее переживание, которое указывает на какую-то невыводную, первичную ценность. Жертвенная практическая установка по отношению к другу позволяет, в итоге, приобщиться к един- 
ственной подлинной (невыводной и первичной) ценности, то есть достичь атараксии. Очевидно, что достижение конечной цели в этом случае возможно лишь непрямыми методами. Оно требует от мудреца двухуровневого ценностно-нормативного мышления. Но отчетливое понимание того, что именно остается конечной целью, никуда не исчезает. Хотя «желанность» блага друзей не зависит от ситуации (эпикуреец не является ненадежным другом), сохраняется она лишь благодаря актуальному осознанию ее связи с атараксией [O'Keefe, 2001, p. 292-207].

Джулия Эннес придерживается иной позиции и рассматривает любовь к друзьям, упоминаемую Цицероном, не как практическую установку, а как чувство, тесно связанное с предельным целеполаганием. Получение наслаждения от заботы о друге, по ее мнению, возможно только в том случае, если я действительно люблю его, то есть рассматриваю благо друга как самодостаточное, невыводное и первичное благо. И если так, то, «помогая другу, я не должен иметь в виду мое собственное наслаждение», несмотря на то, что моей единственной целью является именно оно. При этом Эннес считает такое положение дел шизфореническим, требующим двоемыслия и компартментализации сознания. Сама она сомневается, в том, что двухуровневое мышление, напрашивающееся при чтении этого фрагмента, было свойственно Эпикуру, поскольку этому противоречат другие тексты [Annas, 1995, p. 241-242]. Но если одновременно принять то понимание эпикурейской любви к друзьям, которого придерживается Эннес, и утверждение О’Киффа о двухуровневом характере эпикуровской этики, то перед нами окажется такая двухуровневость, которая затрагивает сами цели. А это значит, что эпикуровское учение о дружбе содержит формулировку парадокса гедонизма. Я хочу получить наибольшее наслаждение, но для этого я должен стремиться не к собственному наслаждению, а к благу друга (Мэтью Эванс обнаруживает парадокс гедонизма непосредственно в реконструкции О’Киффа, но вряд ли это верно [Evans, 2004, p. 414]).

\section{Парадокс гедонизма: новоевропейские сюжеты}

Выстраивая психологический контекст для обсуждения парадокса гедонизма, британский теолог и моральный философ Джозеф Батлер выделяет два типа мотивации, два источника действий, которые объединяет то, что они удовлетворяют «склонности человеческого я». Это «холодный» источник «любви к себе, общего желания себе счастья» и «аффекты, направленные на внешние объекты» [Butler, 2006, p. 111]. Удовлетворение этих аффектов, раз они принадлежат деятелю, конечно, приносит удовольствие именно ему, а не кому-то другому. Поэтому можно было бы говорить о том, что «ни одно создание никогда не может действовать иначе, как из любви к себе». Такое мнение подчас высказывается философами, однако Батлер считает, что «не таков язык, на котором говорит человечество». Любовь к себе, которая заставляет нас желать личного «счастья или блага» и удовлетворяется их получением, необходимо отграничивать от частных аффектов, которые получают удовлетворение «вне зависимости от того, является ли это в целом нашим интересом или счастьем». В первом случае мы говорим о действиях, совершаемых из интереса, во втором - о действиях «страстных, честолюбивых, дружеских, мстительных» и т.д. [Butler, 2006, p. 112]. Парадоксальностью, по Батлеру, характеризуется практическая установка, которая связана с любовью к себе, причем тогда, когда она становится единственным основанием действий.

Эта парадоксальность легко выявляется, если задаться вопросом о том, в какой степени каждое из этих источников или оснований действия в действительности способствует «счастью» или «личному благу». Счастье, как указывает Батлер, не может быть достигнуто на основе чистой любви к себе. Сила любви к себе не пропорциональна степени счастья. Тот, кто больше других любит себя, не обязательно более них счастлив. Если представить себе широкую панораму механизмов получения удовольствия, то роль любви к себе в ней будет довольно ограниченной: любовь к себе может лишь поставить человека 
на путь обретения «тех предметов, которые по природе приспособлены к тому, чтобы доставлять удовлетворение» [Butler, 2006, p. 112]. Впрочем, любовь к себе удовлетворяется даже не посредством обретения этих предметов, а посредством удовлетворения отдельных «страстей, аппетитов и аффектов», направленных на них. В удовлетворении отдельных «страстей, аппетитов и аффектов», собственно, и состоит счастье. Если же любовь к себе поглощает деятеля полностью, то в него душе не остается места для частных переживаний, а это, в свою очередь, делает невозможным полноценное получение удовольствий.

Отталкиваясь от того, что любовь к себе является психическим фактором, который лишь подстегивает стремление к благу или счастью, Батлер делает вывод, что она необходима в ограниченных дозах. Превращаясь в единственный или даже преобладающий мотив, она становится контрпродуктивной - удаляет нас от счастья. Определенная «отрешенность» от собственного интереса, по Батлеру, абсолютно необходима для получения удовольствия, а если она отсутствует, то деятель не может «получить многие из доступных для него видов удовлетворения, которые получают те люди, чей дух свободен и открыт» [Butler, 2006, p. 112]. Характерологическое резюме Батлера звучит следующим образом: «Характер, который мы называем себялюбивым, не самый многообещающий для счастья» [Butler, 2006, p. 112]. Принимая во внимание исходное определение любви к себе (любовь к себе есть стремление к счастью) и исходное определение счастья (счастье есть достаточно сильное и устойчивое удовольствие), это означает, что человек, который охвачен стремлением к удовольствию, не лучший кандидат на получение этого удовольствия. По сути, это и есть наш парадокс. В его итоговой батлеровской формулировке: сильное самолюбие противоречит своей цели - личному благу, а альтернативой ему является умеренное самолюбие и сосредоточенноть на самих по себе естественных страстях и предметах их удовлетворения [Butler, 2006, p. 113].

Как свидетельствует его «Автобиография», Джон Стюарт Милль открыл для себя парадокс гедонизма, столкнувшись в молодости с глубоким духовным кризисом. Понимание этого парадокса стало для него одним из способствующих выходу из кризиса обстоятельств и сформировало экзистенциальную основу его философского учения. Кризис не изменил убеждение Милля в том, что счастье является источником всех правил поведения и конечной целью жизни (следует заметить, что Милль понимает счастье гедонистически - как удовольствие (наслаждение) или правильное сочетание удовольствий (наслаждений)). Однако к этому убеждению добавилось еще одно, касающееся уже средств достижения счастья. «Теперь, - писал Милль, - я стал думать, что эта цель может быть достигнута только если она не превращается в непосредственную цель. Счастливы только те, кто сосредотачивают свое внимание на чем-то ином, а не на своем собственном счастье» [Mill, 1981, p. 145]. Милль перечисляет возможные предметы, которые превращаются из средства достижения счастья в самостоятельную «идеальную цель»: счастье других людей, усовершенствование человечества, искусство, любимые занятия [Mill, 1981, p. 144]. Милль указывает также на причину недостижимости счастья, превращенного в центральную и при этом непосредственную цель жизни. Если «наслаждения жизни» станут такой целью, мы постоянно будем их анализировать и «немедленно почувствуем их недостаточность» [Mill, 1981, p. 146-147]. Однако кроме такого разрушителя наслаждений, как анализ, или критическая рефлексия (questioning, в раннем наброске - self-questioning), он упоминает и другой - «упреждение [наслаждений] в воображении» [Mill, 1981, p. 146147]. Спасает от обоих разрушителей переключение самосознания и способностей к анализу на внешнюю по отношению к счастью жизненную цель. Именно тогда, полагает Милль, «ты вдохнешь счастье с тем воздухом, которым ты дышишь» [Mill, 1981, p. 146147]. Важным ограничивающим замечанием является указание Милля, что этот рецепт работает лишь в отношении тех, кто «имеет умеренную степень чувствительности и способности получать наслаждения», но таких, по его мнению, абсолютное большинство [Mill, 1981, p. 146-147]. 
Элайджа Миллгрэм попытался понять, почему у Милля суммированные в понятии счастья «наслаждения жизни» разрушаются именно тогда, когда мы начинаем их рассматривать как цель, и в чем состоит открывающаяся при этом их «недостаточность». Гипотеза Милгрэма состоит в том, что, превращая счастье в непосредственную цель, мы неизбежно связываем с ним какие-то конкретные отдельные устремления и связанные с ними удовольствия. И так как «наслаждения жизни» не имеют какой-то изначально заданной иерархии, мы всегда рискуем связать какое-то из них со счастьем, а потом оказаться несчастными не столько потому, что не можем достичь, чего мы хотим, сколько потому, что то, с чем мы связали свое счастье, оказалось для нас не так уж и важно (не так приятно). А если не устанавливать такой связи, то счастье вообще не должно превращаться в отправную точку нашей деятельности, оно оказывается вторичным эффектом достижения конкретных целей, важность которых для себя мы устанавливаем эмпирически, по ходу жизни [Millgram, 2019, p. 104]. Если Миллгрэм и прав, то лишь частично. Во всяком случае, его объяснение не охватывает разрушительную роль «упреждения» наслаждений в воображении. Вполне возможно, что упоминаемая Миллем «недостаточность» связана с тем, что способность получать удовольствие подрывают попытки принципиального гедониста сравнивать между собой разные потенциальные удовольствия, выступающие в качестве основы принятия решений. Если постоянно думать о том, что именно в определенной деятельности приносит наибольшее удовольствие (какие ее аспекты), или постоянно думать о том, а нет ли какой-то альтернативной деятельности, которая принесет больше удовольствия, то концентрация на деятельности, способная доставить максимум удовлетворения, окажется невозможной (к этому выводу близок Томас Гурка [Hurka, 2011, p. 44-50]).

В своем понимании парадокса гедонизма Генри Сиджвик следует за Батлером, разграничивая между собой психические импульсы, приносящие нам удовольствие, но на удовольствие прямо не нацеленные, и собственный интерес деятеля, его любовь к себе, которая состоит в стремлении получить наибольшее количество удовольствий. Он обсуждает в этой связи первичные влечения, подобные голоду, и вторичные желания, прямо связанные с удовольствиями, подобные желанию наслаждаться едой. Сиджвик анализирует специфику взаимодействия между ними в двух базовых случаях: «удовольствий от обретения» и «удовольствий от преследования». Первые касаются простого использования тех или иных благ (еды, тепла и т.д.). Вторые, составляющие значительную часть наслаждения жизнью, связаны с какой-то деятельностью и нарастают по мере роста вовлеченности в нее [Sidgwick, 1962, p. 44-47]. Именно их получение порождает эффекты, ведущие Сиджвика к формулировке «фундаментального парадокса гедонизма». Итак, в случае «удовольствий от достижения» влечение менее отчетливо отличается от следующего за его удовлетворением приятного переживания и не проявляет несовместимости с ним. Обжора, поглощенный стремлением насладиться едой, не подрывает своим стремлением аппетит, служащий условием возможности его наслаждения. А вот в случае с «удовольствиями от преследования» складывается иная ситуация. Сиджвик пишет: «Человек, который постоянно поддерживает эпикурейскую установку, неизменно сохраняя в качестве основной сознательной цели свое собственное удовольствие, не чувствует полноты духа этой гонки, его рвение никогда не получает той остроты, которая придает наслаждению его высшую живость» [Sidgwick, 1962, p. 48]. В этом и состоит парадокс.

Итак, удовольствие от деятельности, будь то физической, интеллектуальной или эмоциональной, «не может быть получено в его наибольшей степени, пока мы сконцентрированы на нем в качестве высшей сознательной цели» [Sidgwick, 1962, p. 49]. На чем же надо концентрироваться, чтобы все же получить наибольшую степень удовольствия? На некоторых, «связанных с озабоченностью внешними вещами» импульсах, причем до такой степени, чтобы они превратились в преобладающие и всепоглощающие. Такая самоотверженность, такое придание качеству деятельности высшей и независимой ценности необходимы для успешных и приносящих удовлетворение занятий бизнесом, познанием, искусством. В самой радикальной форме эта зависимость выражена Сиджвиком в виде 
формулы: «чтобы получить... [удовольствия от преследования], о них следует забыть» [Sidgwick, 1962, p. 49].

\section{Парадокс гедонизма в современных концепциях обоснования морали}

В современной этике парадокс гедонизма часто рассматривается в двух перспективах. Первая - перспектива философской психологии и феноменологического анализа состояний сознания. Здесь преобладает стремление теоретиков разобраться с истоками парадокса, с его реальным или мнимым характером. Вторая - перспектива философской теории счастья и смысла жизни. Она соответствует этике в ее широком, античном значении, связанном с формированием оптимального образа жизни, с выбором наилучших стратегий для обретения полноценного человеческого существования («качества жизни» в широком смысле этого термина). Здесь парадокс превращается в критерий отсеивания негодных в эвдемонистическом отношении практических установок. Есть и третья перспектива, пользующаяся достижениями двух предыдущих. Она принадлежит моральной философии и связана с охарактеризованной в начале статьи проблемой обоснования морали.

Исторически эта перспектива присутствовала далеко не везде, где возникал обсуждаемый парадокс. Мы не найдем ее у Платона и Аристотеля. К ней оказывается близок Эпикур, хотя имплицитное присутствие парадокса в его этике связано не с универсализованным альтруизмом, а с альтруизмом партикулярным (жертвенным отношением к другу). Новоевропейские прецеденты связаны с обоснованием морали теснее. Батлер обсуждает парадокс в проповеди о любви к ближнему и в контексте вывода о том, что собственный интерес деятеля, в конечном итоге, не тождественен поглощенностью удовольствием и не противоположен благожелательности, которая есть одно из направленных во вне влечений. Милль среди вещей, превращение которых в цель косвенно ведет к счастью, упоминает счастье других людей и усовершенствование человечества. Сиджвик, хотя и не перечисляет моральную добродетель в исходном списке непрямых источников «удовольствия от преследования», в итоге солидаризируется с мнением, что «удовольствие от добродетели - одно из тех, которые можно получить только при условии, что оно не будет объектом стремления» [Sidgwick, 1962, p. 50].

Будучи перенесенным в контекст обоснования морали рассуждение о парадоксе гедонизма предъявляется моральному скептику, который является эгоистом или готов превратиться в него. И тот, понимая, что вытекающая из его сомнения линия поведения контрпродуктивна в том, что касается получения максимума удовольствия, перестает сомневаться в необходимости моральных самоограничений и связанных с ними потерь. Если представить такой вариант обоснования морали в виде последовательных шагов, то мы получим следующую картину.

Шаг первый воспроизводит сам парадокс. Моральный философ указывает скептику, что удовольствие имеет определенные внешние источники - это объекты, которыми индивид обладает или к которым он имеет доступ, а также практики, в которых он участвует. Если не стремиться ко всем этим вещам ради них самих, то субъективный эффект от их обретения в виде приятных переживаний не будет максимальным. Стремление к таким источникам удовольствия ради них самих тождественно приданию им самостоятельной объективной значимости, не зависящей от разнообразия людей и от изменения установок конкретного человека с течением времени. Если ты хочешь получить высшее удовольствие от обладания чем-то или доступа к чему-то, надо обладать чем-то наилучшим или иметь доступ чему-то наилучшему, причем наилучшему не только в смысле «наилучшему средству удовлетворения моего случайного желания», а наилучшему в соответствии с неизменным объективным стандартом качества. К примеру, наслаждение произведением искусства оказывается лишь тогда наивысшим, когда оно не просто нравится или вызывает восхищение, но и признается объективно прекрасным - творением гения, обладающим вневременной ценностью. Радость дружбы или романтической любви оказывается силь- 
нее, если друг или возлюбленный не просто вызывает субъективное чувство привязанности и желание быть вместе, но и воспринимается как достойный дружбы или любви, как имеющий ценность, независимо от моих чувств в его отношении.

Шаг второй. У признания тех или иных источников счастья объективно ценными есть неизбежная обратная сторона. В отдельных случаях такое отношение к ним существенно ограничивает возможности деятеля получать дополнительные позитивные переживания или избегать негативных. Можно сильно пострадать или даже погибнуть, пытаясь сохранить для мира художественное творение или защитить друга. Однако разумный гедонист не просто считает эти потери оправданными, он не усматривает в них никакой жертвы, поскольку лишь присутствие в его жизни объективно значимых объектов и практик превращает ее в наполненную самыми интенсивными и устойчивыми удовольствиями.

Шаг третий. Если для получения наибольшего удовольствия требуется постулирование объективной ценности его источников, то гедонист должен сформировать такой взгляд на мир, который предполагает недопустимость игнорирования любой из объективных ценностей, а также недопустимость подмены объективных ценностей субъективными предпочтениями. Одной из объективных ценностей являются жизнь и благополучие другого человека. Это вытекает из понимания равенства людей в качестве гедонистических деятелей. Задавшись вопросом: «Является ли мое удовольствие более ценным для меня, чем удовольствие другого человека для него?» и не найдя аргументов в пользу отрицательного ответа, гедонист, пришедший к необходимости признания объективных ценностей, приходит и к необходимости морального самоограничения.

Данное рассуждение является несколько модифицированной логикой обоснования морали, использующейся Полом Блумфилдом. Он прямо отталкивается от выводов Батлера и Сиджвика, носящих скорее психологический, чем нормативный характер, и помещает их в контекст аргументационного противостояния моральному скептику (Блумфилд избирает для этих целей персонажа Уилки Коллинза графа Фоско) [Bloomfield, 2014, p. 96-103]. На третьем шаге его рассуждения присутствует не только аргумент от равенства людей как объективной ценности, но и аргумент от невозможности самоуважения (а оно есть условие успешного гедонистического и эвдемонистического опыта) в случае пренебрежения благом другого человека [Bloomfield, 2016, 2014]. Несколько дальше от приведенной выше модели находится вариант обоснования морали, предложенный в последней главе трактата Питера Сингера «Практическая этика» (глава имеет название «Зачем действовать морально») [Singer, 2011, p. 276-296]. Здесь парадокс гедонизма превращается в способ доказательства того, что на нулевом уровне моральной чувствительности - уровне человека с психопатическими тенденциями - невозможно обретение смысла жизни. Именно такому человеку обращен аргумент о том, что удовольствие, превращаясь в самостоятельную цель, подрывает само себя, и рекомендация «смотреть вовне, на что-то более долговременное и далеко простирающееся» [Singer, 2011, p. 292]. В отношении того, что человек, понявший парадоксальность удовольствия и превратившийся в «благоразумного эгоиста, должен предпочесть именно моральную «большую цель», Сингер использует другие аргументы.

Я не буду пытаться развернуть здесь полноценную дискуссию о плюсах и минусах такого обоснования морали, но бегло укажу на некоторые его проблемные точки. Первая проблема связана с оговоркой Милля, что парадокс гедонизма значим не для всех людей, и с теми поправками, которые Сиджвик вносит в рассуждение Батлера. Напомню, по его мнению, парадокс гедонизма касается не всех удовольствий, а лишь тех, которые связаны с особого рода деятельностями, «удовольствиями преследования». Как показывает Томас Гурка, в случае с некоторыми пассивными удовольствиями наилучший эффект дает именно прямая сосредоточенность на эффективности разных средств получения приятных переживаний, сопровождающаяся возможностью свободно варьировать эти средства [Hurka, 2011 , p. 46]. Соответственно, гедонистическая жизненная стратегия могла бы быть сориентирована на удовольствия именно пассивного типа (на их получение в максимальном количестве), а удовольствия активного типа могли бы играть в ней подчиненную и второстепен- 
ную роль. Однако дело в том, что пассивные удовольствия гораздо больше подвержены ловушкам привыкания и никакая культура пассивного наслаждения не может их преодолеть. Специфика активных удовольствий состоит в том, что они привязаны к процессу совершенствования и, значит, их «обновление» дается гораздо легче [Hurka, 2011, p. 49-50].

Вторая проблема касается возможности того, что гедонист, переубежденный аргументом от парадокса удовольствия, сосредоточится на объективных, но при этом неморальных целях и ценностях. Он может использовать миллевско-сиджвиковский список видов деятельности: профессия, познание, искусство, непрофессиональные любимые занятия и именно в них получать максимально интенсивные активные удовольствия. Существуют довольно весомые ответы на это возражение. Раз эгоистический гедонист признал объективность одних ценностей, то и все остальные ценности ему приходится проверять на объективность. И если такая проверка дает положительный результат, то эти ценности приходится реализовывать в деятельности уже вне зависимости от интенсивности получаемого от этого удовольствия. Сингер добавляет к этому соображение, построенное не на рациональности (тот, кто проигнорировал бы моральные ценности, найдя другие способы косвенного получения удовольствия, по его мнению, не иррационален), а на повышенной рефлексивности в отношении собственной жизни. Моральные цели таковы, что их невозможно исчерпать и «перерасти» [Singer, 2011, p. 294].

Третья проблема проступает в реакции Эннес на предположение, что в этике Эпикура имплицитно присутствует парадокс гедонизма. Она, напомню, предположила, что опора на этот парадокс требует недостижимого волевого раздвоения сознания и полного замыкания возникших частей в себе. В свете парадокса гедонизма гедонистический деятель должен и хотеть, и не хотеть получения удовольствий. Рецепт Сиджвика - «если хочешь получить удовольствие, забудь о нем»- сталкивается с подозрением, что произвольно забыть причины выбора объективно значимых целей в момент их реализации просто невозможно. Это подозрение попытался разрушить Питер Рэйлтон. Он предположил, что так называемый «утонченный гедонист» сталкивается не с тупиком, а всего лишь с психологической проблемой. Наблюдая жизнь других людей, которые больше его счастливы в связи с их искренней привязанностью к друзьям или искренней любовью к спортивной игре в противоположность желанию наград и славы, он может пытаться перефокусировать свои устремления. Критики, по его мнению, недооценивают возможность существования смешанных мотиваций [Railton, 1984, 143-146].

Гораздо сложнее обстоят дела с обоснованием объективной ценности нравственной (то есть универсально альтруистической) линии поведения. Даже признание того, что удовольствие другого человека значит для него столько же, сколько мое для меня, не влечет автоматически вывода о том, что я должен бескорыстно содействовать его удовольствию. Впрочем, это затруднение обоснования морали возникает не на том этапе, который использует парадокс гедонизма.

\section{Список источников}

1. Аристотель. 1984. Никомахова этика. В кн.: Аристотель. Сочинения в 4 т. Т. 4. М., Мысль: 53-294.

2. Платон. 1994. Филеб. В кн.: Платон. Собрание сочинений в 4 т. Т. 3. М., Мысль: С. 7-78.

3. Цицерон. 2000. О пределах добра и зла. Парадоксы стоиков. М., Российск. гос. гуманит. ун-т, 2000: 474 с.

\section{Список литературы}

1. Прокофьев А.В. 2017. Почему я должен быть моральным? (теоретический контекст обоснования морали). Этическая мысль, 17(1): 5-17. DOI: 10.21146/2074-4870-2017-17-1-5-17

2. Annas J. 1995. The Morality of Happiness. N.Y., Oxford University Press: 502 p.

3. Aufderheide J. 2011. The Value of Pleasure in Plato's Philebus and Aristotle's Ethics. Thesis submitted for the degree of Doctor of Philosophy. St Andrews, University of St Andrews: $217 \mathrm{p}$.

4. Bloomfield P. 2016. Morality is Necessary for Happiness. Philosophical Studies, 6: 1-16. 
5. Bloomfield P. The Virtues of Happiness: A Theory of the Good Life. N.Y., Oxford University Press: 253 p.

6. Butler J. 2006. Fifteen Sermons Preached at the Rolls Chapel. In: The Works of Bishop Butler. Rochester, University of Rochester Press: 33-146.

7. Evans M. 2004. Can Epicureans Be Friends? Ancient Philosophy, 24 (2): 407-424.

8. Harte V. 2018. Plato's Philebus and the Value of Idle Pleasure. In: Virtue, Happiness, Knowledge: Themes from the Work of Gail Fine and Terence Irwin. Oxford, Oxford University Press: $111-128$.

9. Hurka T. 2011. The Best Things in Life: A Guide to What Really Matters. Oxford, Oxford University Press: 200 p.

10. Mill J.S. 1981. Autobiography. In: The Collected Works of John Stuart Mill. Vol. I. Toronto, University of Toronto Press: 1-291.

11. Millgram E. 2019. John Stuart Mill and the Meaning of Life. Oxford, Oxford University Press: 288 p.

12. O'Keefe T. 2001. Is Epicurean Friendship Altruistic? Apeiron, 34 (4): 269-304.

13. Railton P. 1984. Alienation, Consequentialism, and the Demands of Morality. Philosophy \& Public Affairs, 13 (2): 134-171.

14. Sidgwick H. 1962. The Methods of Ethics. L., Palgrave Macmillan: 528 p.

15. Singer P. 2011. Practical Ethics. Cambridge, Cambridge University Press: 337 p.

\section{References}

1. Prokof'ev A.V. 2017. Why should I be moral? (the theoretical context of justification of morality). Eticheskaya mysl', 17(1): 5-17. Ethical Thought, 17 (1): 5-17 (in Russian). DOI: 10.21146/2074-4870-2017-17-1-5-17

2. Annas J. 1995. The Morality of Happiness. N.Y., Oxford University Press: 502 p.

3. Aufderheide J. 2011. The Value of Pleasure in Plato's Philebus and Aristotle's Ethics. Thesis submitted for the degree of Doctor of Philosophy. St Andrews, University of St Andrews: 217 p.

4. Bloomfield P. 2014. The Virtues of Happiness: A Theory of the Good Life. N.Y., Oxford University Press: 253 p.

5. Bloomfield P. 2016. Morality is Necessary for Happiness. Philosophical Studies, 6: 1-16.

6. Butler J. 2006. Fifteen Sermons Preached at the Rolls Chapel. In: The Works of Bishop Butler. Rochester, University of Rochester Press: 33-146.

7. Evans M. 2004. Can Epicureans Be Friends? Ancient Philosophy, 24 (2): 407-424.

8. Harte V. 2018. Plato's Philebus and the Value of Idle Pleasure. In: Virtue, Happiness, Knowledge: Themes from the Work of Gail Fine and Terence Irwin. Oxford, Oxford University Press: 111-128.

9. Hurka T. 2011. The Best Things in Life: A Guide to What Really Matters. Oxford, Oxford University Press: 200 p.

10. Mill J.S. 1981. Autobiography. In: The Collected Works of John Stuart Mill. Vol. I. Toronto, University of Toronto Press: 1-291. Press: $288 \mathrm{p}$.

11. Millgram E. 2019. John Stuart Mill and the Meaning of Life. Oxford, Oxford University

12. O'Keefe T. 2001. Is Epicurean Friendship Altruistic? Apeiron, 34 (4): 269-304.

13. Railton P. 1984. Alienation, Consequentialism, and the Demands of Morality. Philosophy \& Public Affairs, 13 (2): 134-171.

14. Sidgwick H. 1962. The Methods of Ethics. L., Palgrave Macmillan: 528 p.

15. Singer P. 2011. Practical Ethics. Cambridge, Cambridge University Press: 337 p.

\section{ИНФОРМАЦИЯ ОБ АВТОРЕ}

Прокофьев Андрей Вячеславович, доктор философских наук, ведущий научный сотрудник сектора этики института философии РАН, профессор кафедры философии и культурологии Тульского государственного педагогического университета им. Л.Н. Толстого, Россия

\section{INFORMATION ABOUT THE AUTHOR}

Andrey V. Prokofyev, DSc in Philosophy, Leading Research Fellow. RAS Institute of Philosophy. Professor, the Department of Philosophy and Culturology. Tula State Lev Tolstoy Pedagogical University. Russia 